S2 Figure. Coverage distribution per gene. For each gene a graph is depicted, showing the mean coverage per exon over all samples $(n=34)$. Error bars reflect \pm 1 standard deviation. The commonly used threshold of $30 \mathrm{X}$ coverage is indicated in each graph with a black line.

\title{
Gene A
}

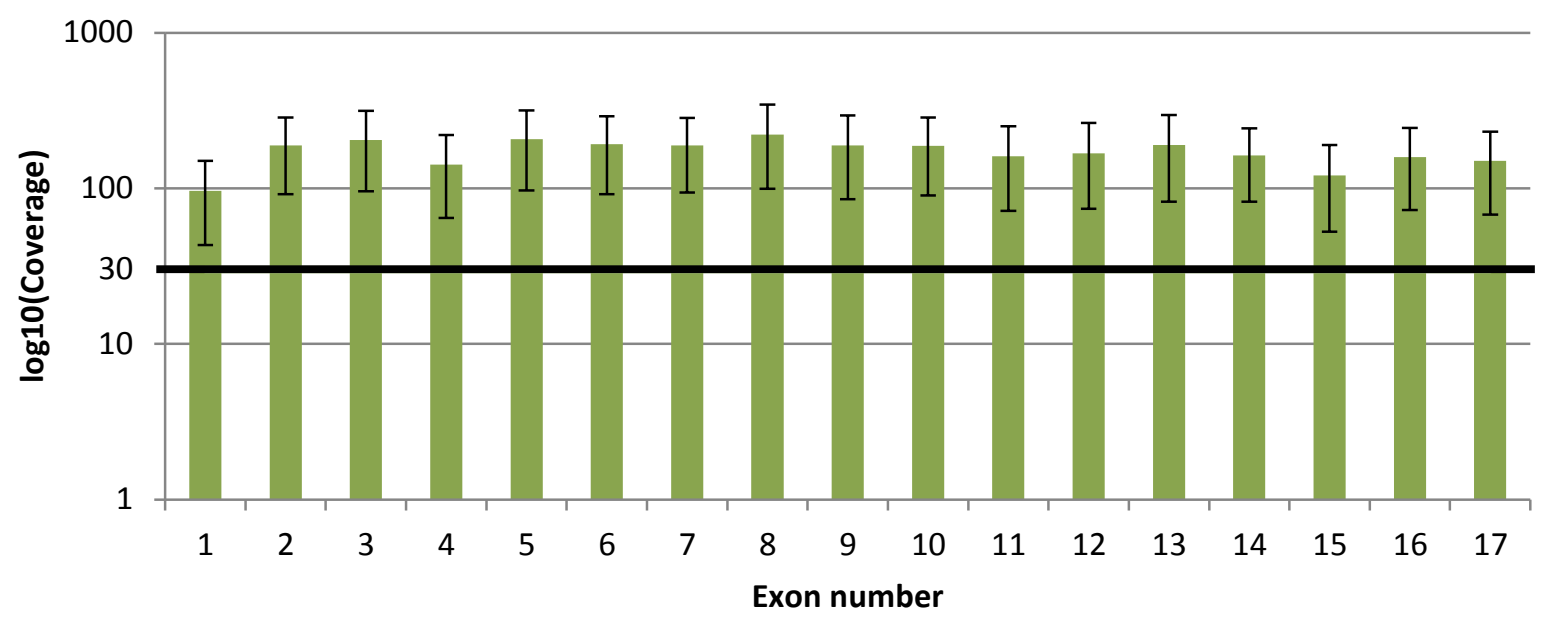

Gene B

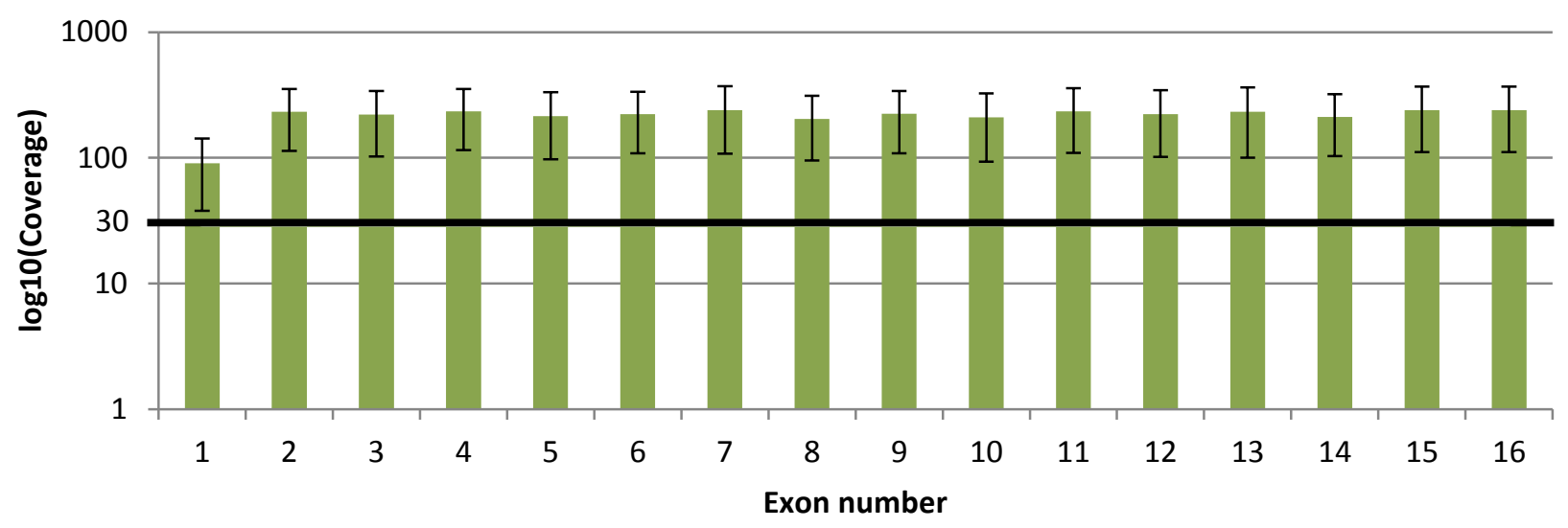

Gene C

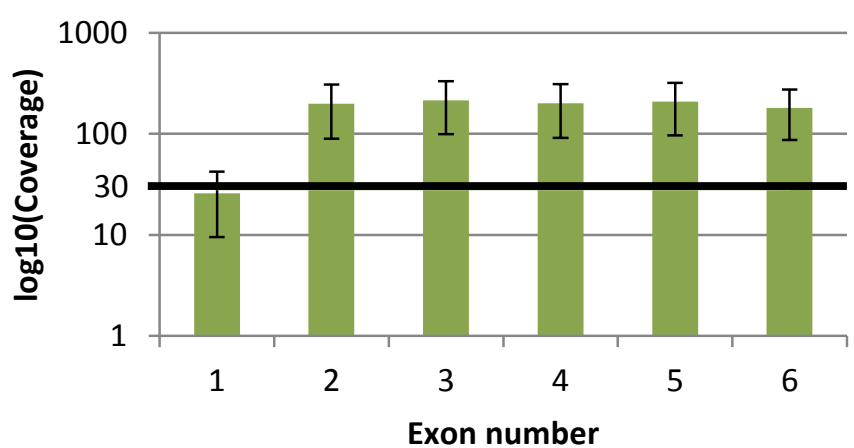

Gene D

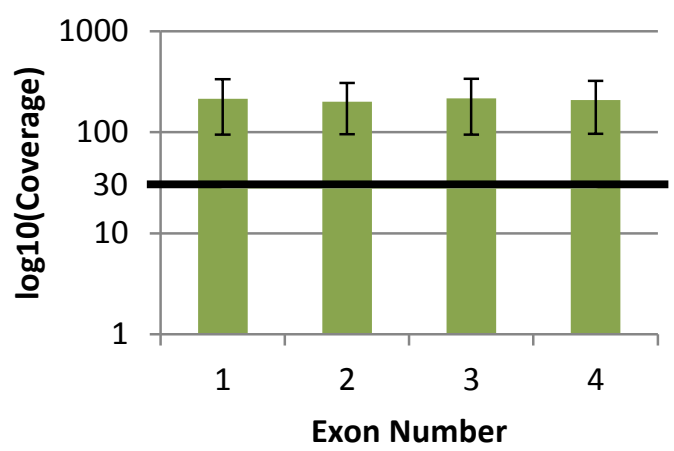




\section{Gene E}

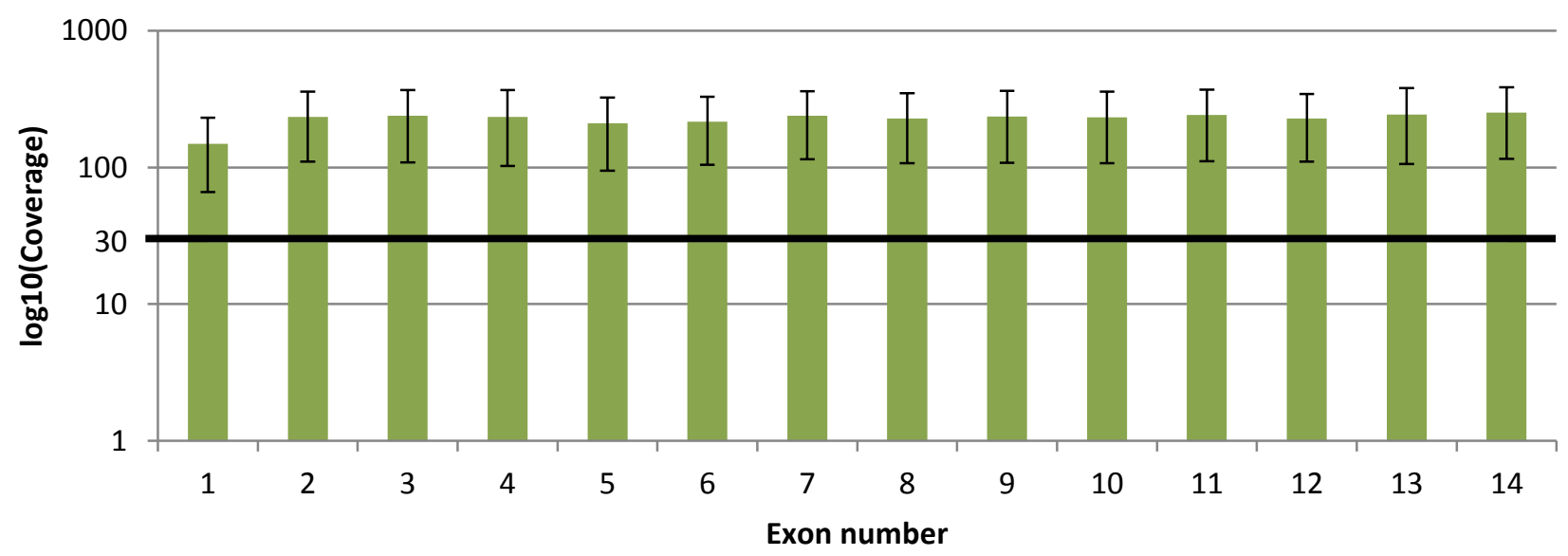

\section{Gene F}

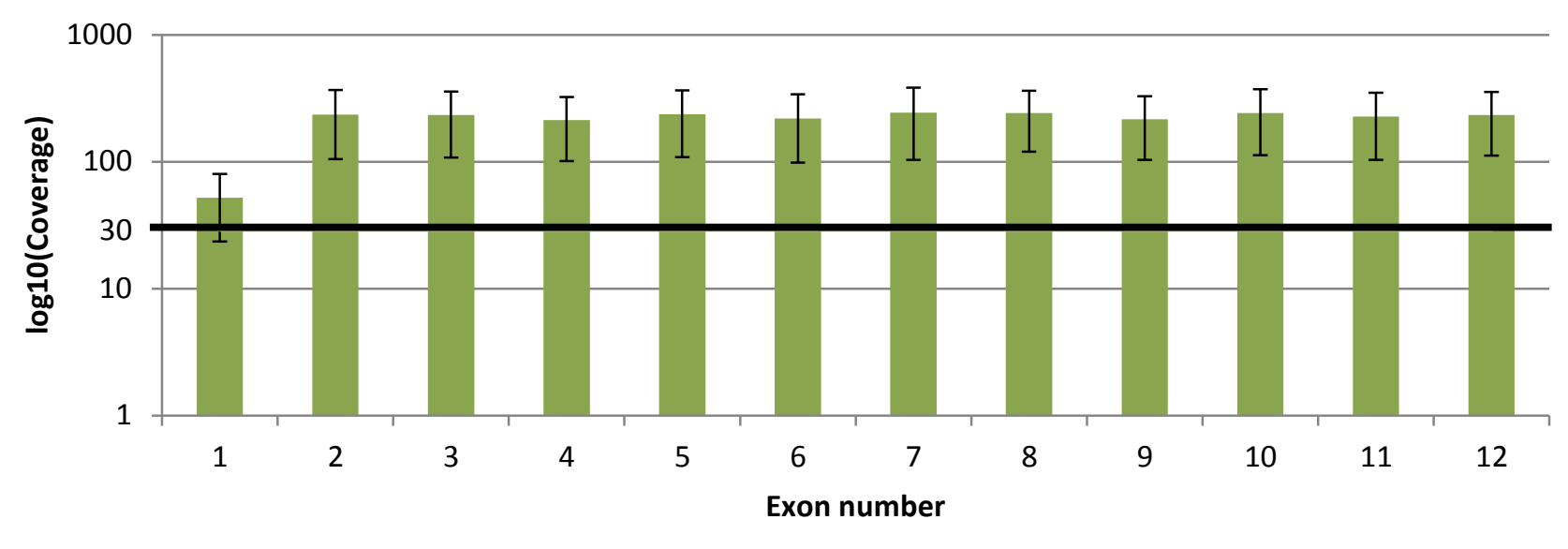

Gene G

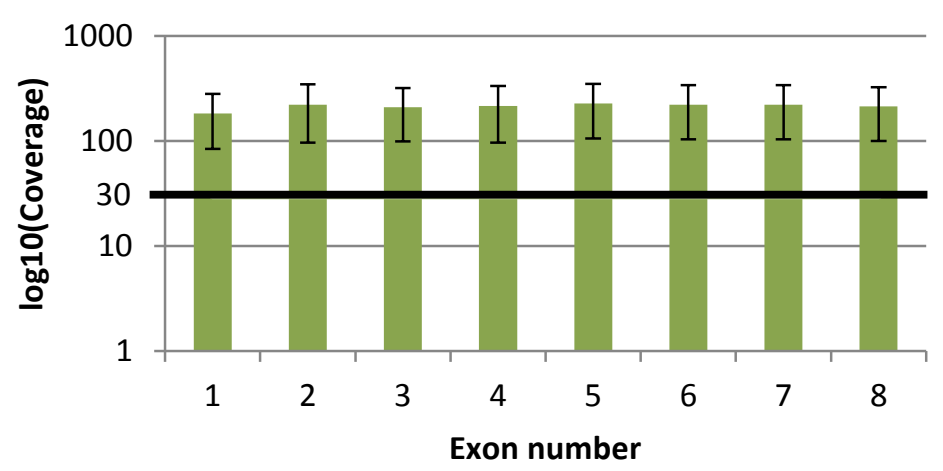

Gene I

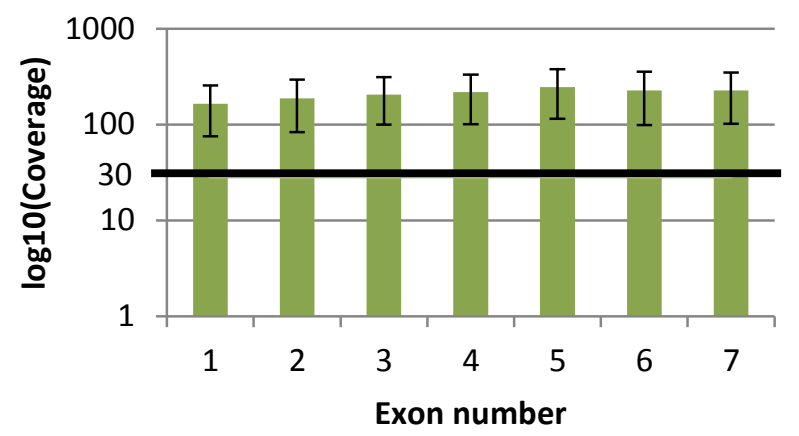

Gene H

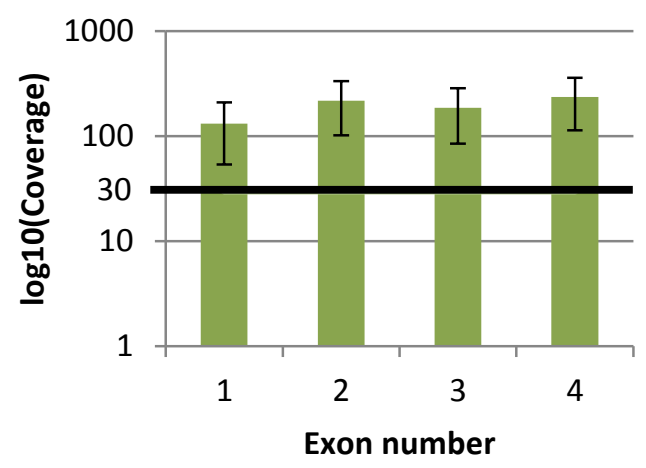

Gene J

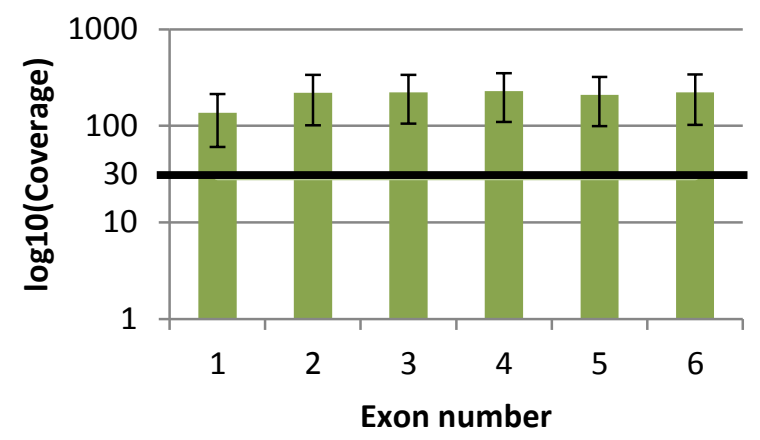




\section{Gene K}

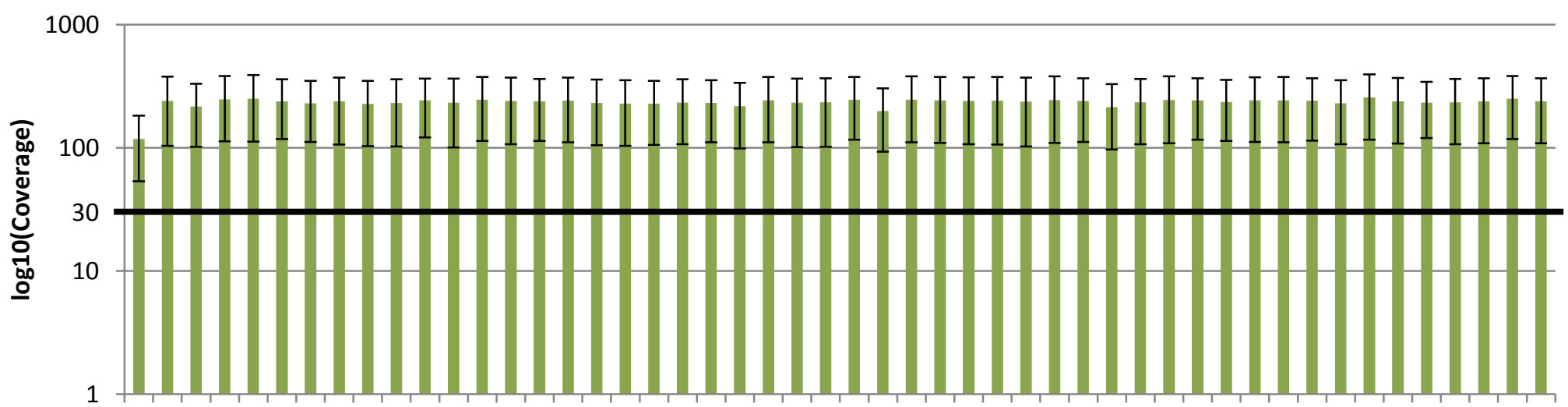

1234567891011121314151617181920212223242526272829303132333435363738394041424344454647484950 Exon number

\section{Gene L}

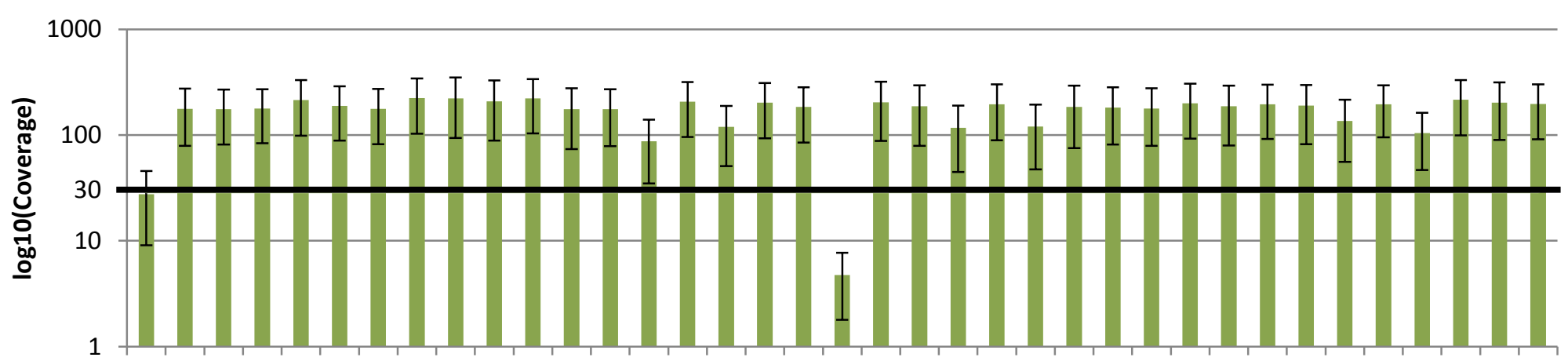

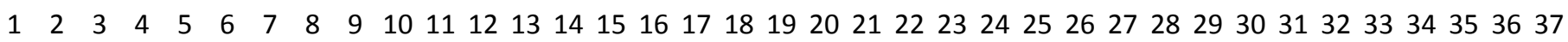
Exon number

\section{Gene M}

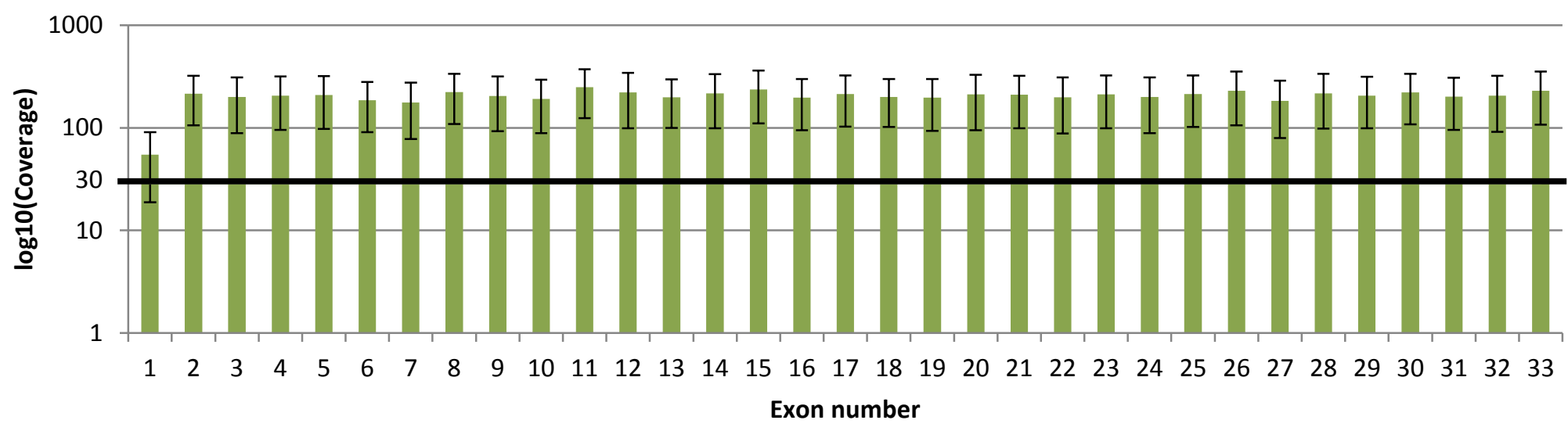

\section{Gene N}

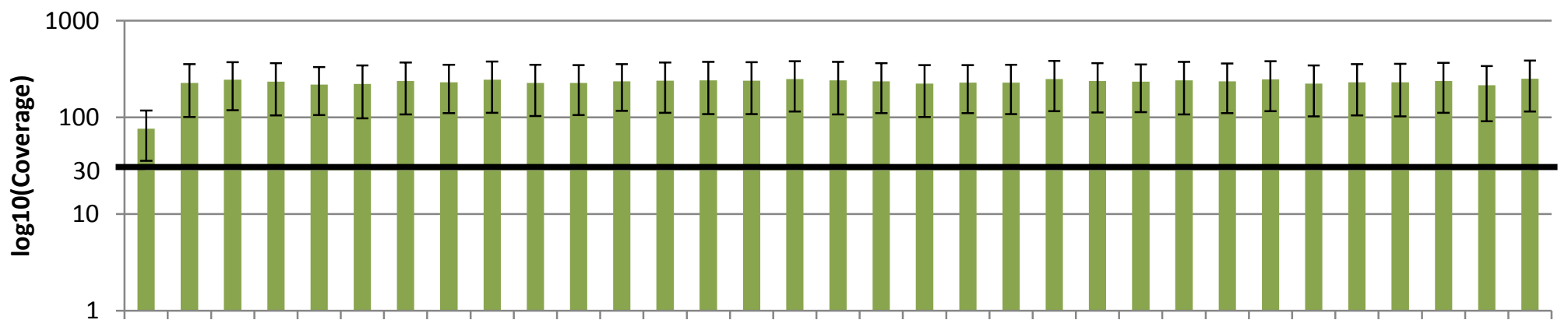

$\begin{array}{lllllllllllllllllllllllllllllllll}1 & 2 & 3 & 4 & 5 & 6 & 7 & 8 & 9 & 10 & 11 & 12 & 13 & 14 & 15 & 16 & 17 & 18 & 19 & 20 & 21 & 22 & 23 & 24 & 25 & 26 & 27 & 28 & 29 & 30 & 31 & 32 & 33\end{array}$ 


\section{Gene 0}

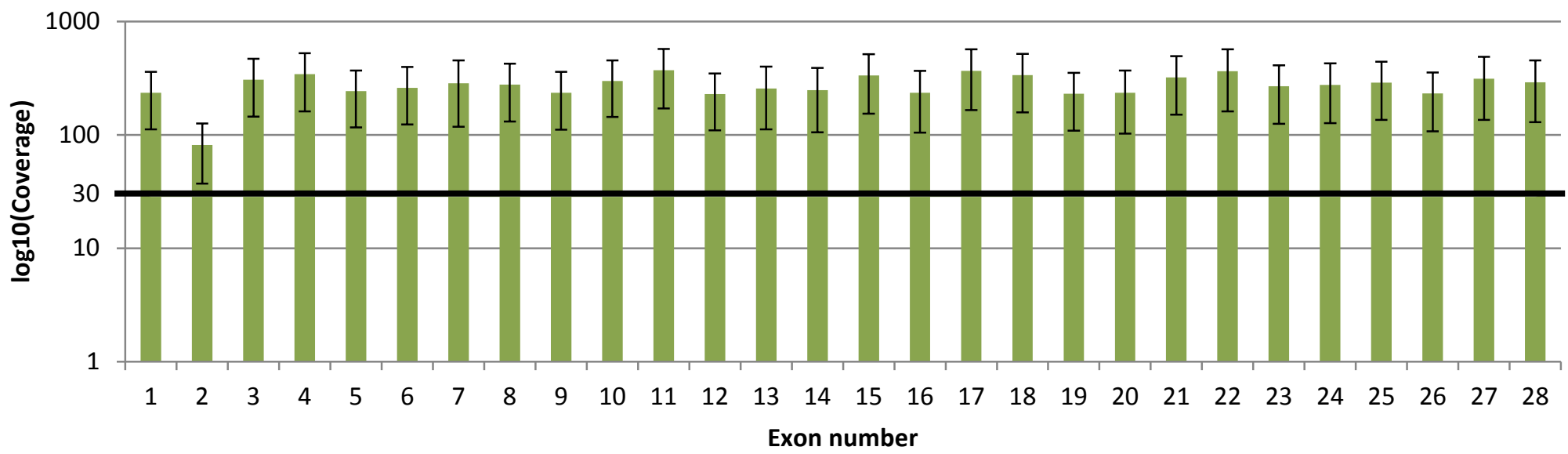

\section{Gene P}

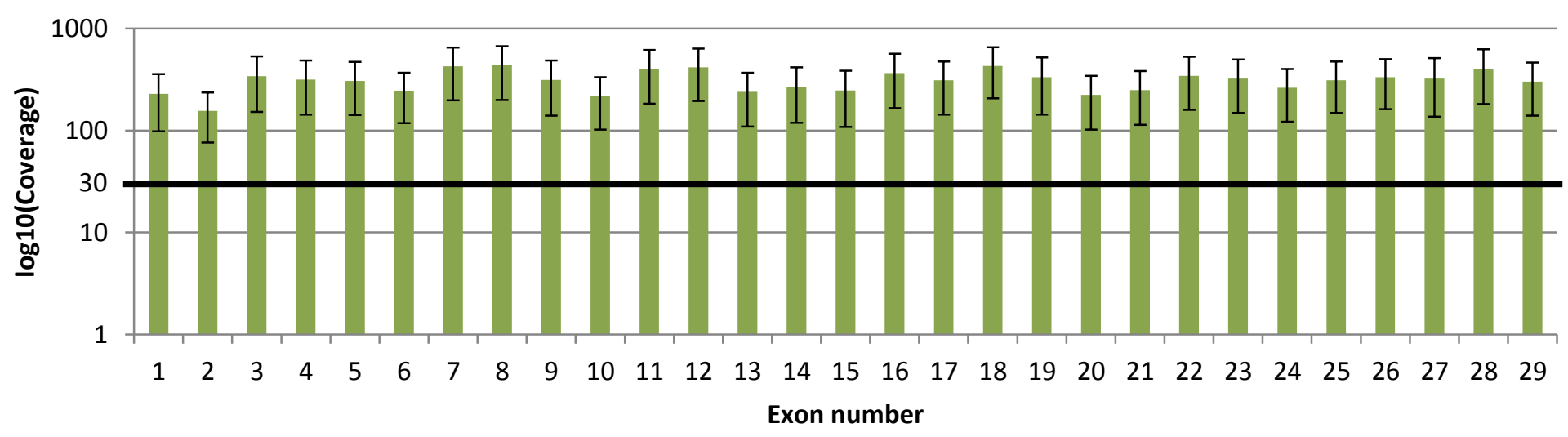

Gene Q

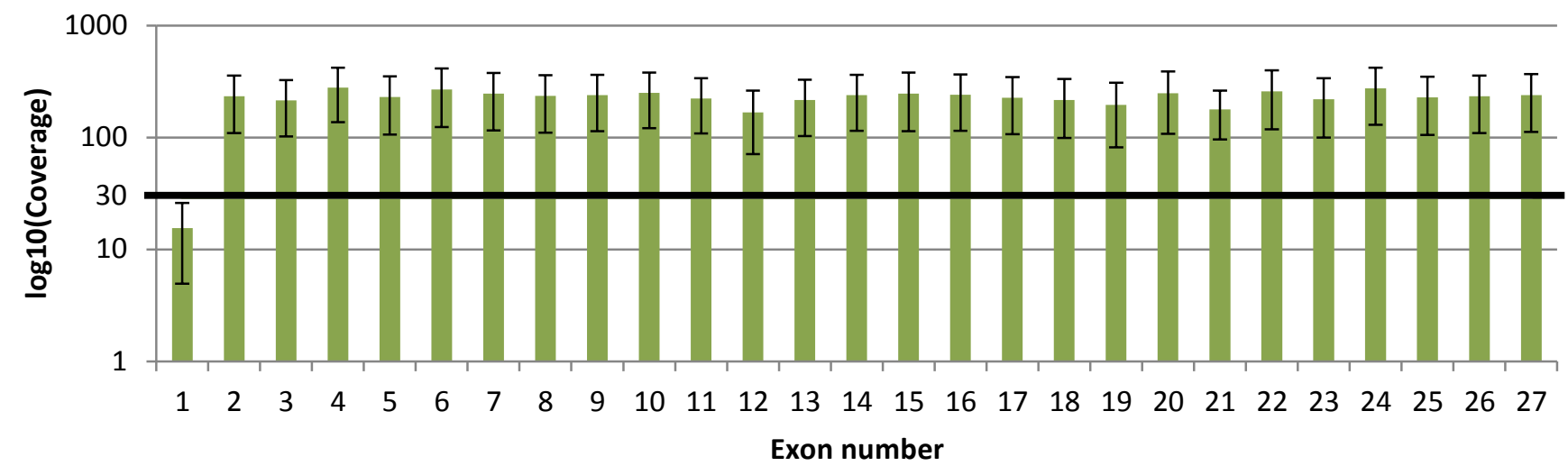

Gene R

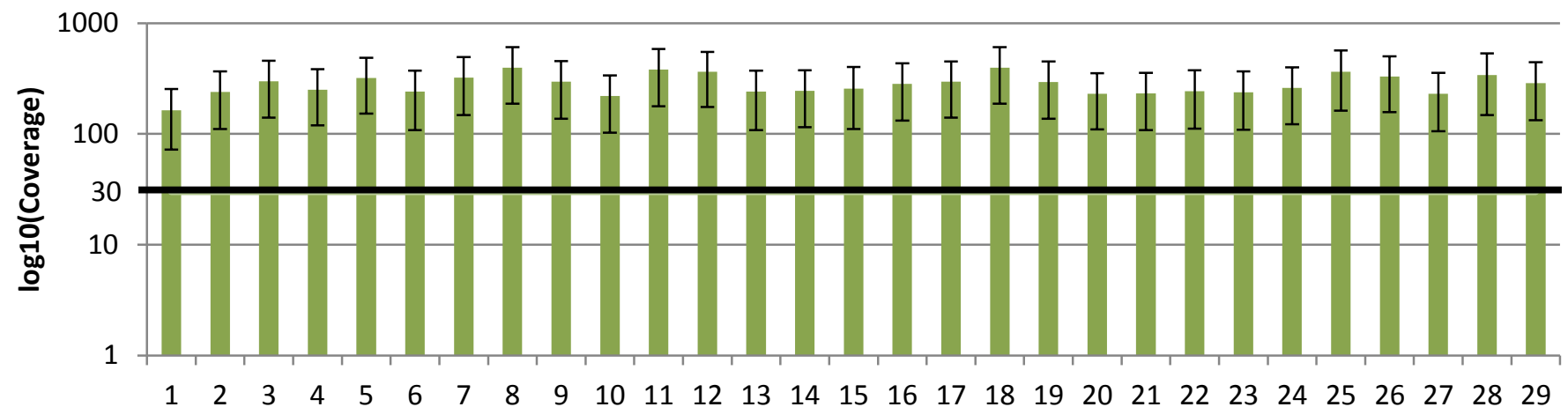

